\title{
What Drives Shadow Banking in the New EU Member States? Empirical Panel Cointegration Approach
}

\author{
Jordan KJOSEVSKI* - Mihail PETKOVSKI** - Aleksandar STOJKOV***
}

\begin{abstract}
The central goal of this paper is to analyse factors that determine the growth of shadow banking in 11 new EU member states from Central and Eastern Europe, using annual data for the period 1999 - 2019. As the levels of economic and financial development vary considerably across these countries, we split them into three more homogenous groups: the Balkan, Baltic, and Višegrad countries. We then applied dynamic and fully modified ordinary least squares to estimate the relationship between the variables. The results of our study indicate that the insurance and banking sectors as well as economic growth have a positive effect on the shadow banking sector across all groups. We also found that the global financial crisis (GFC) of 2007 - 2008 had a diverse impact on the selected groups of countries.
\end{abstract}

Keywords: shadow banking, procyclicality, panel cointegration

JEL Classification: G21, E44, E50

DOI: https://doi.org/10.31577/ekoncas.2021.08.03

\section{Introduction}

Shadow banking has become an increasingly popular mode of financial intermediation, providing market-based financing for many firms and households. This intermediation outside the traditional banking system is carried out by

\footnotetext{
* Jordan KJOSEVSKI, corresponding author, Silk Road Bank, Pitu Guli 5, Ohrid, Republic of Macedonia; e-mail: jordan_kos@yahoo.com

** Mihail PETKOVSKI, Ss. Cyril and Methodius University, Faculty of Economics, Department of Financial Management, Blvd. Goce Delchev 9V, 1000 Skopje, Republic of Macedonia; e-mail: mihailpetkovski@yahoo.com

*** Aleksandar STOJKOV, Ss Cyril and Methodius University, Iustinianus Primus Law Faculty, Department of the Faculty of Law and Economics, Blvd. Goce Delcev 9b, 1000 Skopje, Republic of Macedonia; e-mail: a.stojkov@pf.ukim.edu.mk
} 
a broad range of non-bank financial intermediaries that now constitute an important part of the modern financial systems (Financial Stability Board, 2011; European Commission, 2012). However, the under-regulated shadow banks may become a source of systemic risk, both directly and through their links with the conventional banking system (Financial Stability Board, 2019). The rapid growth of shadow banking over the past two decades is a major concern not only for national authorities but also for international financial institutions, such as the International Monetary Fund (IMF), the Bank for International Settlements (BIS), and the European Central Bank (ECB).

This paper aims to fill an important gap in the empirical literature investigating the driving forces behind the evolution of the shadow banking sector in 11 new EU member states (Bulgaria, Croatia, the Czech Republic, Estonia, Hungary, Latvia, Lithuania, Poland, Romania, the Slovak Republic, and Slovenia) from 1999 to 2019. Considering that economic and financial development vary considerably across these countries, we split them into three more homogenous groups: the Balkan countries (BAL-4), Baltic countries (B-3), and Višegrad countries (VIS-4). To the best of our knowledge, this is the first time that NMS are classified into sub-samples and separately analysed. To test the hypothesised relationship between shadow banking and the explanatory variables, we employed the fully modified ordinary least squares (FMOLS) and dynamic ordinary least squares (DOLS) estimation techniques. According to Du, Li and Wang (2017), all these countries have shared a socialist central planning system in the past and are still making significant efforts towards establishing a well-functioning financial system, thereby depriving shadow banking of a context that could allow its institutions and activities to flourish.

In the literature, different alternatives of measurement have been advanced in theory and practice, designed to accommodate the increasing complexity of shadow banking. One widely employed measure involves using the aggregated financial assets of other financial intermediaries (OFIs) as an instrument to measure shadow banking (an 'entity-based' approach). OFIs include all non-bank financial corporations and quasi-corporations that are mainly engaged in financial intermediation and primarily provide long-term funding. In general terms, OFIs do not include central banks, banks (all deposit-taking corporations), insurance corporations, pension funds, public financial institutions, and financial auxiliaries. This measure was initially adopted by the FSB, which also made a distinction between a broader and narrower approach, with the latter filtering out non-bank financial activities that have no direct relation to credit intermediation (e.g., equity investment funds) or that are already prudentially consolidated into banking groups (FSB, 2014; 2015). 
Nonetheless, this measure is often contested because it accounts for entities that are not engaged in shadow banking activities, thus overstating the true dimensions of shadow banking in many countries. To remedy this deficiency, 'activity-based' approaches for measuring shadow banking have been advanced. The FSB proposed a new 'economic function-based' measure of shadow banking, classifying non-bank financial institutions in accordance with five economic functions that involve non-bank credit intermediation with some risks to financial stability (FSB, 2015). Although activity-based approaches are generally considered more accurate, it is not yet possible to use these measures of shadow banking for the new EU member states from CEE because of limited data availability. In fact, the most complete financial data source on this regional group is the Eurostat, which only reports data on assets and liabilities in the financial sector, disaggregated by sub-sectors. Due to this limitation, the entity-based approach was adopted in measuring shadow banking. Moreover, based on the FSB's distinction between the broad and narrow approaches and the structure of available data for the NMS, we considered the broad approaches. The broad approach includes all non-monetary financial institutions, except insurance corporations and pension funds. Therefore, from the overall financial sector, the following institutions are excluded: monetary and financial institutions (central banks, deposit-taking corporations, and money market funds [MMF]), public financial institutions, insurance corporations, and pension funds.

The paper is organised as follows: Section 1 discusses the importance of shadow banking in the 11 new EU member states. Section 2 briefly reviews the existing cross-country studies on the determinants of shadow banking. Section 3 introduces the data while Section 4 describes the methodology employed. Section 5 presents the empirical results, and Section 6 synthesises the study findings to offer policy-relevant recommendations.

\section{Importance of Shadow Banking in the New EU Member States}

With regard to the shadow banking sector, the situation of the new EU member states is different in many respects compared with the other, more developed EU nations. Before the financial crisis of 2007 - 2008, shadow banking experienced a significant growth in Europe, including in countries from Eastern Europe. For example, in the period 2002 - 2007, the total assets of shadow banking institutions grew by $14.6 \%$ on average in the EU and $23 \%$ in the 11 countries from Eastern Europe - now new EU member states. After 2008, in the euro area, shadow banks' total assets grew at sustained rates in the run-up to the crisis and continued to increase afterwards, even though at a slower pace, reaching the 
maximum by the end of 2017 compared with 2002 when they were near 10 trillion EUR. The size of the EU shadow banking system of total assets were just over 42 trillion EUR at the end of 2017, accounting for around 40\% of the EU financial system. In the same year, the total assets of shadow banking in the 11 new EU member states were near 400 billion EUR, compared with 2002 when it was near 70 billion EUR.

However, as noted by Ghosh et al. (2012) and Du, Li and Wang (2017), although the shadow banking system has grown markedly in these countries, its size remains relatively small. Nonetheless, in these countries, the shadow banking system has grown in complexity and leverage, as well as in interconnectedness with the traditional banking sector (Giron and Matas-Mir, 2017; Portes, 2018) to an extent that it now forms an integral part of the regular financial system.

Fig u r e 1

Main Structural Components of the Financial System in NMS

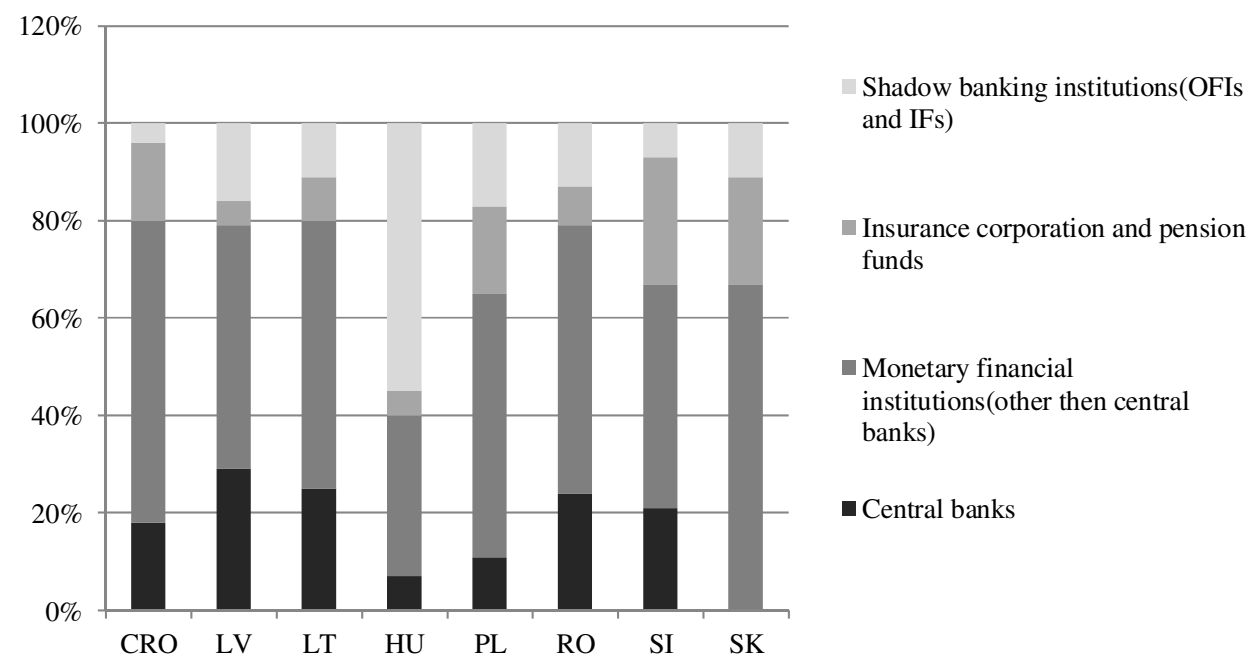

Source: Eurostat.

Looking at the main structural components of the financial system in the NMS countries in 2017 (Figure 1), one can notice among them a relatively similar distribution regarding the total volume of assets (homogenous dispersion). The share of the assets of shadow banking institutions in the total assets of the financial system in NMS countries ranges from almost $6 \%$ to about $21 \%$, with the exception of Hungary where shadow banking institutions own more than half of the Hungarian financial system's assets (54.4\%). Traditional banks own assets that usually exceed half of the financial system's total volume of assets, with figures ranging 
between $48 \%$ and $70 \%$ (except for Hungary). To sum up, all the NMS, excluding Hungary, have traditional banking systems that dominate their national financial systems in terms of total assets and a rather small but increasing shadow banking system, followed by central banks, insurance corporations, and pension funds.

Furthermore, if we analyse the size of the shadow banking system as the value of the total assets of other financial intermediaries (OFIs), expressed as a percentage of the GDP, we can see from Figure 2 that the share of the GDP is constantly growing in almost all countries. As mentioned, Hungary has the biggest share of OFIs expressed as a percentage of the GDP. In the period under review, Hungary had the highest growth rate, but due to the low base of the growth, it does not mean that the country managed to catch up with more developed countries. An important aspect of the shadow banking system in Hungary is non-money market investment funds. By 2016, non-money market investment funds had a bigger role in Hungary and Poland, where the risks inherent in the shadow banking system are more likely to be found in the sector of other financial intermediaries. While the most crucial shadow banking institutions in developed countries are non-money market mutual funds, in Eastern European countries, other financial institutions (OFIs, i.e., leasing, factoring, and debt collection service companies) dominate the shadow banking sector. In the context of the relative underdevelopment of the asset management market, OFIs play a more influential role in the shadow banking system in Hungary than in other countries (Mérö and Bethlendi, 2020).

Figure 2

The Share OFIs, Expressed as a Percentage of the GDP in the 11 New EU Member States

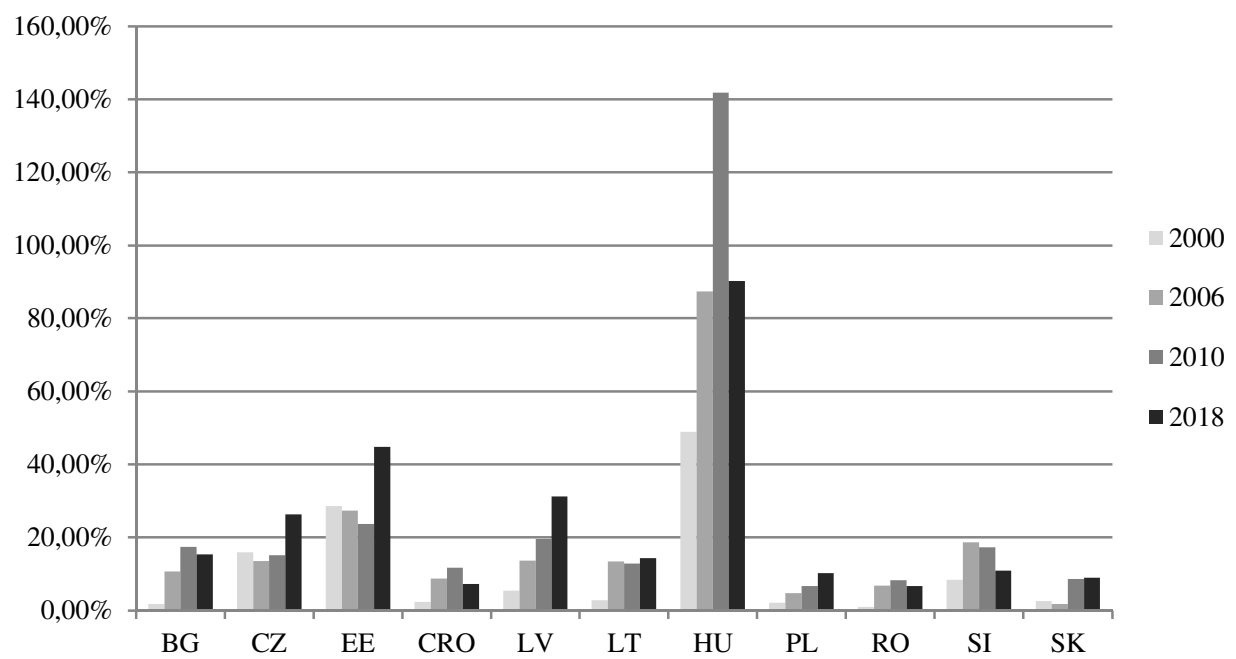

Source: Eurostat different years. 
When defining and interpreting the shadow banking system as a term, not only should the special institutions and methods traditionally linked to the system be considered but also the special forms of appearance corresponding to the activity. In Hungary, this special form of appearance could be discussed, but doubtlessly about the phenomena that can be defined as and which operates as a shadow banking system. Such phenomena include broker scandals and 'pyramid schemes' resulting from the lack of financial awareness. The Hungarian supervisory bodies and institutions (including the Hungarian Financial Supervisory Authority and National Bank of Hungary) were not able to supervise the activities of these company groups adequately and lead them in the proper direction by means of different legal regulatory systems (Bujtár and Kecskés, 2015).

Instead of investing the capital gained from issuing bonds in profit table and yield-producing assets and portfolios, on the one hand, they mainly pay maturing bonds and due interest from it, and on the other hand, in the long run, they invest only in high-risk industries with high yields.

\section{Literature Review}

Given the primary objective of this study, we have limited the literature review only to cross-country investigations on the determinants of shadow banking in a European context and in the aftermath of the global financial crisis (GFC). It is important to note that the definitional problems of the EU member states were satisfactorily resolved by a commonly agreed definition adopted by the European Systemic Risk Board (ESRB). Accordingly, the Eurostat produces internationally comparable and reliable data on the size of shadow banking systems in the EU and European Economic Area.

IMF (2014) analysed determinants of shadow banking in a sample of 26 most developed economies, which also included some European countries for the 1990 - 2013 period. The results indicate that tightening of banks' capital requirements, expanding of traditional banking, and institutional investors' growth had a positive impact on the growth of shadow banking. The cross-national study indicates that short-term interest rates have a negative effect on shadow banking's growth.

Malatesta, Masciantonio and Zaghini (2016) estimated the empirical relevance of selected determinants of shadow banking in the Eurozone countries over the period 1999Q1 - 2014Q1. Their estimation results reveal that the loans granted by shadow banks were mainly driven by macroeconomic factors, such as the GDP growth, inflation, and interest spread. 
Barbu, Boitan and Cioaca (2016) investigated determinants of shadow banking for a panel of $15 \mathrm{EU}$ member states (including four Central and Eastern European economies) using quarterly data (2008Q1 - 2015Q3). They used the net value of the total assets of shadow banks as proxy for the size of this sector. The results indicate that economic growth, short-term interest rates, liquidity, and the development of investment funds have a negative effect on shadow banking, while stock index and long-term interest rates have a positively effect.

Hodula (2018), using system-GMM estimator, estimated factors that determine shadow banking growth in a sample of 24 EU countries for the $2004-$ 2017. He found that more stringent capital regulation and faster financial development positively impact shadow banking growth. He also identified a difference between between the 'old' and new EU member states due to the missing legal framework for securitisation in the new member states.

Apostoaie and Bilan (2019), using quarterly data from 2004 to 2017, analysed determinants of shadow banking dynamics in $11 \mathrm{EU}$ member states from Central and Eastern Europe. They utilised two versions of the dependent variable, a broad one and a narrow one. Further, they used six macroeconomic and financial factors as explanatory variables. Their findings indicate that economic growth and the traditional banking sector positively impact the shadow banking sector in the selected countries. Furthermore, the results show that a higher demand for funds from institutional investors and low interest rate supports the expansion of the shadow banking sector.

In sum, the evolution of shadow banking has been found to be supported by the expansion of the traditional banking system, the growth of institutional investors, and favourable macroeconomic conditions. The procyclicality hypothesis has received mixed empirical support, whereas there is some evidence that short-term interest rates impede shadow banking's growth. A general remark to consider is the problem of omitted variable bias - the noted studies do not account for the stringency of the financial regulation and the legislative framework for securitisation.

\section{Data}

Our study dataset consists of a sample of 11 new EU members states (NMS) from Central, Eastern, and Southeastern Europe (Bulgaria, Croatia, the Czech Republic, Estonia, Hungary, Latvia, Lithuania, Poland, Romania, the Slovak Republic, and Slovenia) and uses annual data from 1999 to 2019.

The selection of countries was based on their increasing political, economic, and institutional integration with the European Union (EU). Despite the macroeconomic similarities growing interconnectedness between their economies, and 
geographical and cultural proximity, these countries do not constitute a homogenous group. In fact, the aggregate pattern masks significant heterogeneities in terms of the key variables, such as the real GDP growth, inflation rate, level of financial development, etc.

Given that the levels of economic and financial development vary considerably across these countries, we classified the emerging Europe into three more homogenous groups: the Višegrad group of countries (VIS-4) - Hungary, Slovakia, the Czech Republic, and Poland; the Baltic group of countries (B-3) Lithuania, Latvia, and Estonia; and the Balkan group of countries (BAL-4): Bulgaria, Croatia, Romania, and Slovenia.

The core determinants selected in our model have been previously used in academic literature (Kim, 2016; Barbu, Boitan and Cioaca, 2016; Apostoaie and Bilan, 2019). The internationally comparable and reliable data were obtained from a variety of sources: the Eurostat, European Systemic Risk Board (ESRB), IMF's International Financial Statistics and Monetary and Financial Statistics database, European Central Bank's Statistical Data Warehouse database, and the World Bank's World Development Indicators.

Considering the definitional ambiguities of the shadow banking system (SBS), it is difficult to empirically map the dependent variable. As already mentioned, there has not been an internationally harmonised definition of SBS for a sufficiently long period. Hence, when specifying the econometric model and selecting the variables, we had to search for an 'appropriate' measure of the size of shadow banking that would be comparable across the selected group of countries. In empirical terms, we followed the approach by Kim (2016) and Apostoaie and Bilan (2019) to define the size of a shadow banking system as the value of the total assets of other financial intermediaries (OFIs), expressed as a percentage of the GDP.

The official data were obtained from the Eurostat. Our broad definition of shadow banking includes the financial sector, except for banks, pension funds and insurance companies, public financial institutions, and financial auxiliaries. One advantage of the OFI statistics is the high degree of international consistency, which implies that they can be compared and aggregated across countries (Broos et. al., 2012).

Based on the theoretical guidance received from the literature review, the following explanatory variables were used:

- macroeconomic determinants: real GDP growth ( $g d p g)$; inflation rate (infl); and interest spread (in percentage points), i.e., the lending rate less the deposit rate (margin), 
- financial determinants: the asset size of banks as a percent of the GDP (bank), insurance companies' penetration as a percent of the GDP (penetra), and a financial development index (findev), and

- a dummy variable for the occurrence of the global financial crisis of 2007 2008 (crisis).

Real GDP growth. At the core of all previously mentioned studies, the variables related to the gross domestic product (GDP) are among the main macroeconomic determinants in shadow banking's growth. In this context, several variations of these determinants, such as the annual growth rate of the real GDP, the growth of income per capita, etc., are well known in the literature. However, the real GDP growth rate is by far the most common macroeconomic determinant, used, for example, by Duca (2016), Malatesta, Masciantonio and Zaghini (2016), and Hodula, Melecky and Machacek (2017). Bearing in mind the procyclicality hypothesis Adrian and Shin (2009) and studies of Duca (2016) and Malatesta et al. (2016), we expect a positive and significant impact of the real GDP growth.

The rate of inflation is defined as the annual growth rate of the consumer price index. The justification for its inclusion in the model is to capture the effect of the loss in purchasing power among investors on their decisions to shift their investments towards shadow banking (IMF, 2014).

Interest spread. Inspired by Martinez-Miera and Repullo (2015) and Kim (2016), our model includes banks' net interest margin, computed as the difference between the interest rate paid on deposits to savers and the interest rate on loans to borrowers. This determinant aims to test the validity of the search-foryield hypothesis in the banking approach. More precisely, in circumstances of a lower net interest margin (interest spread), banks will have more incentives to shift their operations towards shadow banking and expect higher returns.

Financial determinants. The model also includes variables representing other segments of the financial systems in the countries under investigation: the asset size of banks and insurance companies' penetration, both expressed as a percentage of the GDP. Bearing this in mind, the institutional cash pool hypothesis and the empirical evidence by IMF (2014), Malatesta, Masciantonio and Zaghini (2016), and Apostoaie and Bilan (2019), we expect that these variables will be positively associated with the growth of the shadow banking sector. To capture financial innovations or financial developments, we followed Kim (2016) to include a financial development index. The measure of financial development was adopted from Svirydzenka (2016), which considers the depth, access, and efficiency of financial institutions or financial markets in a comprehensive manner. Although the financial development index may partly represent financial innovations primarily brought by shadow banks, we expect a positive association between this determinant and shadow banking's growth. 
Global Financial Crisis. We also included a binary dummy for the occurrence of the global financial crisis (GFC) and assigned a value of one for the period from 2007 to 2008 and a value of zero for all other periods. This approach is also consistent with the new European financial crises database, provided by the ESRB (2016).

T a ble 1

\section{Descriptive Statistics}

\begin{tabular}{|l|c|c|c|c|c|c|c|}
\hline & ofi & gdpg & infl & spread & bank & penetra & findev \\
\hline Mean & 21.89 & 3.262 & 3.953 & 4.904 & 57.94 & 2.807 & 0.354 \\
Median & 11.75 & 3.602 & 2.8 & 4.482 & 58.48 & 2.7 & 0.346 \\
Maximum & 185.9 & 11.88 & 45.80 & 20.74 & 169 & 6 & 0.575 \\
Minimum & 0.4 & -14.81 & -1.544 & 1.361 & 10.9 & 0.71 & 0.122 \\
Standard deviation & 32.81 & 3.895 & 5.495 & 3.042 & 22.75 & 1.110 & 0.093 \\
Number of observations & 228 & 231 & 231 & 206 & 213 & 221 & 209 \\
\hline
\end{tabular}

Source: Authors' calculations,

The heterogeneity in economic growth rates ( $g d p g$ ) is remarkable: the annual GDP growth varies from almost $12 \%$ to nearly $-15 \%$. Further, the size of the shadow banking system (ofi) displays large differences, ranging from a minimum of $0.4 \%$ of GDP up to a maximum of $185.9 \%$. Such substantial differences among the 11 NMS justify the classification of the sample countries into three more homogeneous sub-groups to conduct a more precise investigation of the determinants of shadow banking. As illustrated in Figure 3, the three sub-groups differ in terms of their average income levels, the highest being observed in the Višegrad group of countries. The income level of countries is positively correlated with their level of financial development (Figure 4).

Figure 3

Figure 4

Average Income Levels of the Three Groups Scattergram of the Levels of Economic of Countries, 1999 - 2018 and Financial Development
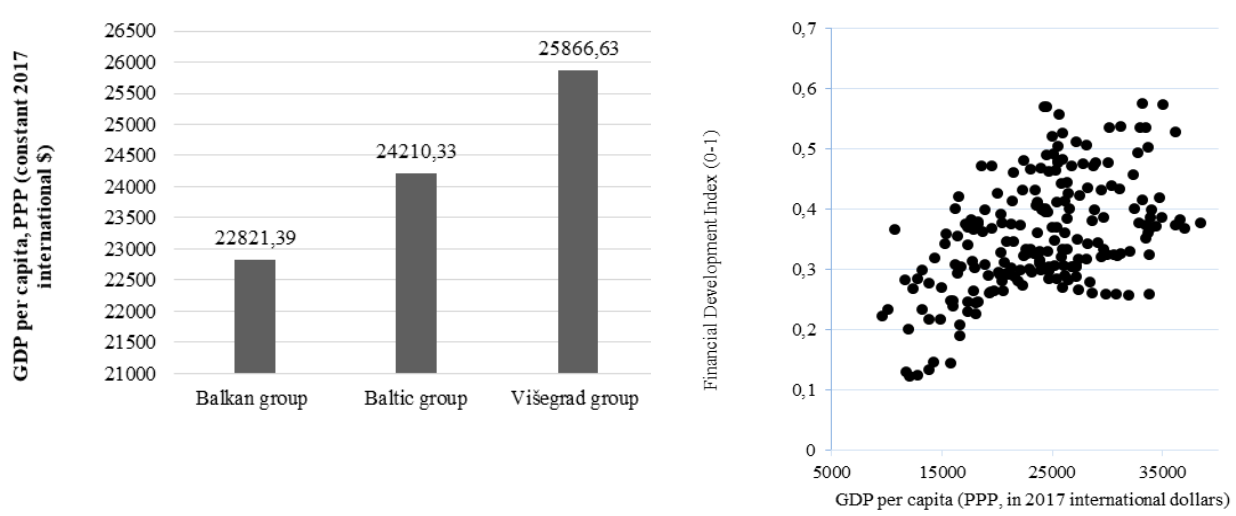

Source: World Bank's World Development Indicators. 


\section{Methodology}

The empirical strategy implemented in this study is based on panel data analysis. According to Maddala (2001), one of the main advantages of panel data estimation is that it allows for the testing and adjustment of assumptions that are implicit in a cross-sectional analysis. The econometric model is depicted by equation (1):

$$
S B_{i t}=\beta_{j} D E T_{j, i, t}+u_{i, t}
$$

where $i$ refers to the country $(I=1-11) ; t$ refers to time periods (years) $(t=1-19)$; $S B_{i, j}$ is the dependent variable, i.e., a measure of shadow banking's growth; $D E T_{i, j}$ is a vector of the determinants of shadow banking's growth; $\beta_{j}$ are the coefficients of these explanatory variables; and $u_{i, t}$ are the idiosyncratic errors.

Before proceeding to the econometric method, we needed to verify the stationarity of the variables selected. In this study, we performed a panel analysis and panel unit root tests - the Im-Pesaran-Shin (IPS) test (2003) and two alternatives of a Fisher-type test (augmented Dickey-Fuller (ADF) and Phillips-Perron (PP) test), as outlined by Maddala and Wu (1999). These tests allow for the deterministic and dynamic effects differing across the panel members. In this study, a $10 \%$ level of importance was applied as a critical value for determining whether the time series is stationary. Furthermore, to estimate the existence of a long-run relationship between the dependent variable and the explanatory variables, we tested the cointegration equations in the panel. In this study, we used two cointegration tests - Pedroni (1999) and Kao (1999) - to test the null hypothesis of no cointegration between the selected determinants.

Having established the cointegration tests, the next step was to estimate the long-term relationship between the variables. The literature proposes different estimation methods for panel cointegration models. In this study, we used the fully modified ordinary least square (FMOLS) and the dynamic ordinary least squares (DOLS) estimators. We chose these methods for several reasons. Firstly, the OLS estimator is biased and inconsistent when applied to a cointegrated panel. On the other hand, the DOLS and FMOLS estimators take care of both small sample bias and endogeneity bias by taking the leads and lags of the first-differenced regressors (Kao and Chiang, 2000). Secondly, for panels that have a larger time dimension $(T)$, the dynamic estimator of the generalised method of moments (GMM) is not very effective as it is more applicable when the number of the cross-sectional units is higher than the time periods (Roodman, 2009). In this research, the time dimension $(T=20)$ was much greater than the cross-sectional dimension $(N=11)$. Thirdly, these estimators allow for greater flexibility with heterogeneity in the examined cointegrated vectors (Pedroni, 1999; 2001). 
Furthermore, Banerjee (1999) argued that the results from any of these two estimations are asymptotically equivalent for more than 60 observations. Our study in all three models meets this criterion.

However, the DOLS parametric approach is preferred over the FMOLS nonparametric one because the latter imposes additional requirements that all variables of the same order I(1) be integrated and the regressors themselves not be cointegrated (Masih and Masih, 1996). Additionally, according to Kao and Chiang (2000), the FMOLS estimator is complicated by the dependence of the correction terms upon the preliminary estimator, which may be very biased in finite samples with panel data. The DOLS estimator has the additional advantage of controlling the endogeneity in the model as the augmentation of the lead and lagged differences of the regressor suppresses the endogenous feedback (Lean and Smyth, 2010; Afonso and Jalles, 2012). This indicates that the DOLS estimator may be more promising than the OLS or FMOLS estimator in evaluating cointegrated panel regressions.

With a view to explain the idea of the FMOLS estimator, we referred to the following fixed-effects model:

$$
S B_{i, t}=\alpha_{i}+x_{i, t}^{\prime} \beta+u_{i, t}
$$

where, $i(=1,2 \ldots N)$ and $t(=1,2 \ldots T)$ indexes are the cross-sectional units and time series units respectively, $S B_{i, t}$ is the shadow banking (an I(1) process), $\beta$ is the vector of parameters, $\alpha_{i}$ are intercepts, and $u_{i, t}$ are the stationary disturbance terms. Here, $x_{i, t}$ are assumed to be the vector of explanatory variables, which are $I(1)$ for all cross-sectional units. It is assumed that it follows an autoregressive process in the following form:

$$
x_{i, t}=x_{i, t-1}+\varepsilon_{i, t}
$$

with an innovation vector $w_{i, t}=\left(u_{i, t}, \varepsilon_{i, t}\right)$.

Given that $w_{i, t}=\left(u_{i, t}, \varepsilon_{i, t}\right) \sim I(0)$, the variables are said to be cointegrated for each member of the panel with the cointegrating vector $\beta$. The asymptotic distribution of the OLS estimator is the condition for the long-run covariance matrix of the innovation vector. The FMOLS estimator is derived by making an endogeneity correction (by modifying the variable $S B_{i, t}$ ) and a serial correlation correction (by modifying the long-run covariance of the innovation vector, $w_{i, t}$ ). The resulting final estimator is expressed as follows:

$$
\beta_{F M O L S}=\left[\sum_{i=1}^{N} \sum_{t=1}^{T}\left(x_{i t}-\bar{x}\right)\left(x_{i t}-\bar{x}_{i}\right)^{\prime}\right]^{-1} *\left[\sum_{i=1}^{N}\left(\sum_{t=1}^{T}\left(x_{i t}-\bar{x}\right) \hat{S} B_{i t}-T \hat{\Delta}_{\varepsilon U}\right)\right]^{-1}
$$


The DOLS estimator has been extended to panel analysis by Kao and Chiang (2000), who developed the finite sample properties of the OLS, DOLS, and Pedroni's FMOLS. The DOLS estimator in a panel-case environment is obtained by running the following regression:

$$
S B_{i, t}=\alpha_{i}+\beta_{i} x_{i, t}+\sum_{k=-p_{1}}^{p_{2}} \delta_{k} \Delta S B_{i, t-k}+\sum_{k-q_{1}}^{q_{2}} \lambda_{k} \Delta x_{i, t-k}+u_{i, t}
$$

where $p$ and $q$ denote the numbers of leads and lags typically chosen using certain information criterion (e.g., Akaike, Hansen, etc.).

Based on all the above, further analysis will evaluate the results of the FMOLS and DOLS estimations.

\section{Empirical Results}

In this section, we present the results of the econometric analysis of the determinants of shadow banking's growth in the selected new EU member states. The first step of our empirical analysis was to perform panel unit root tests. As already mentioned in the previous section, we carried out panel-IPS unit root tests and Fisher-type tests using ADF and PP-test, as outlined by Maddala and $\mathrm{Wu}$ (1999). These tests were conducted on both levels and first differences for all variables in the model. Considering the traditional null hypothesis of stationarity, the results indicate accept of stationarity at first difference and reject stationarity at levels indicating that all series are I(1). Following the panel unit root tests' results for all series of interest, the null hypothesis of a unit root cannot be rejected. Since the null hypothesis of a unit root holds for all series of interest, we continued with panel cointegration tests as the next step.

T a ble 2

Panel Unit Root Tests (Balkan countries - BAL-4)

\begin{tabular}{|c|c|c|c|c|c|c|c|}
\hline \multirow[b]{2}{*}{ Variables } & \multicolumn{2}{|c|}{$\begin{array}{c}\text { Im, Pesaran and Shin } \\
\text { W-stat }\end{array}$} & \multicolumn{2}{|c|}{ ADF-Fisher Chi square } & \multicolumn{2}{|c|}{ PP-Fisher Chi square } & \multirow[t]{2}{*}{ Implication } \\
\hline & $\begin{array}{c}\text { At } \\
\text { a level of }\end{array}$ & $\begin{array}{c}\text { First } \\
\text { differentiation }\end{array}$ & $\begin{array}{c}\text { At } \\
\text { a level of }\end{array}$ & $\begin{array}{c}\text { First } \\
\text { differentiation }\end{array}$ & $\begin{array}{c}\text { At } \\
\text { a level of }\end{array}$ & $\begin{array}{c}\text { First } \\
\text { differentiation }\end{array}$ & \\
\hline ofi & -1.15 & $-6.28 * * *$ & 11.27 & $20.48 * * *$ & 9.25 & $32.44 * * *$ & $I(1)$ \\
\hline$g d p g$ & -0.28 & $-5.36 * * *$ & 7.27 & $41.26 * * *$ & $21.44 * * *$ & $112.7 * * *$ & $I(1)$ \\
\hline infl & -1.28 & $-3.99 * *$ & $20.97 * * *$ & $30.75 * * *$ & 11.47 & $66.87 * * *$ & $I(1)$ \\
\hline spread & -0.45 & $-4.08 * * *$ & $13.39 *$ & $31.73 * * *$ & 6.98 & $36.19 * * *$ & $I(1)$ \\
\hline bank & -1.78 & $-3.15 * * *$ & $15.70 * * *$ & $25.28 * * *$ & 4.13 & $37.26 * * *$ & $I(1)$ \\
\hline penetra & -0.23 & $-1.61 * * *$ & 7.58 & $14.61 * *$ & $13.30 *$ & $39.92 * * *$ & $I(1)$ \\
\hline findev & -0.43 & $-3.55 * * *$ & 10.33 & $28.27 * * *$ & 9.64 & $44.70^{* * *}$ & $I(1)$ \\
\hline
\end{tabular}

Note: *, **, and *** indicate that the test statistic is significant at the $10 \%, 5 \%$, or $1 \%$ level.

Source: Authors' calculations. 
Table 3

Panel Unit Root Tests (Baltic countries - B-3)

\begin{tabular}{|l|c|c|c|c|c|c|c|}
\hline \multirow{3}{*}{ Variables } & \multicolumn{2}{|c|}{$\begin{array}{c}\text { Im, Pesaran and Shin } \\
\text { W-stat }\end{array}$} & \multicolumn{2}{|c|}{ ADF-Fisher Chi square } & \multicolumn{2}{c|}{ PP-Fisher Chi square } & Implication \\
\cline { 2 - 8 } & $\begin{array}{c}\text { At } \\
\text { a level of }\end{array}$ & $\begin{array}{c}\text { First } \\
\text { differentiation }\end{array}$ & $\begin{array}{c}\text { At } \\
\text { a level of }\end{array}$ & $\begin{array}{c}\text { First } \\
\text { differentiation }\end{array}$ & $\begin{array}{c}\text { At } \\
\text { a level of }\end{array}$ & $\begin{array}{c}\text { First } \\
\text { differentiation }\end{array}$ & \\
\hline ofi & 1.06 & $-2.08 * * *$ & 3.56 & $14.17 * * *$ & 3.10 & $25.97 * * *$ & $I(1)$ \\
gdpg & -0.54 & $-3.38^{* * *}$ & 10.45 & $22.36 * * *$ & 9.75 & $15.43 * * *$ & $I(1)$ \\
infl & -1.05 & $-4.34 * * *$ & 8.69 & $27.36 * * *$ & 8.44 & $57.73 * * *$ & $I(1)$ \\
spread & -1.27 & $-4.37 * *$ & 10.04 & $11.47 * *$ & $12.61 * *$ & $19.54 * * *$ & $I(1)$ \\
bank & 0.71 & $-5.46 * *$ & 3.36 & $14.02 * *$ & 5.33 & $14.67 * *$ & $I(1)$ \\
penetra & 0.99 & $-2.16^{* * *}$ & 4.45 & $16.34 * * *$ & 5.09 & $40.13 * * *$ & $I(1)$ \\
findev & 0.05 & $-1.42 *$ & 4.89 & $10.87 *$ & $10.89 *$ & $38.11 * * *$ & $I(1)$ \\
\hline
\end{tabular}

Note: *, **, and *** indicate that the test statistic is significant at the $10 \%, 5 \%$, or $1 \%$ level.

Source: Authors' calculations.

Table 4

Panel Unit Root Tests (Višegrad countries - VIS-4)

\begin{tabular}{|c|c|c|c|c|c|c|c|}
\hline \multirow[b]{2}{*}{ Variables } & \multicolumn{2}{|c|}{$\begin{array}{c}\text { Im, Pesaran and Shin } \\
\text { W-stat }\end{array}$} & \multicolumn{2}{|c|}{ ADF-Fisher Chi square } & \multicolumn{2}{|c|}{ PP-Fisher Chi square } & \multirow[t]{2}{*}{ Implication } \\
\hline & $\begin{array}{c}\text { At } \\
\text { a level of }\end{array}$ & $\begin{array}{c}\text { First } \\
\text { differentiation }\end{array}$ & $\begin{array}{c}\text { At } \\
\text { a level of }\end{array}$ & $\begin{array}{c}\text { First } \\
\text { differentiation }\end{array}$ & $\begin{array}{c}\text { At } \\
\text { a level of }\end{array}$ & $\begin{array}{c}\text { First } \\
\text { differentiation }\end{array}$ & \\
\hline ofi & 0.23 & $-4.60 * * *$ & 6.08 & $35.29 * * *$ & 7.71 & $55.21 * * *$ & $I(1)$ \\
\hline$g d p g$ & -0.58 & $-2.26 * * *$ & 13.23 & $18.45^{* * *}$ & $16.20 * *$ & $23.01 * * *$ & $I(1)$ \\
\hline infl & 0.59 & $-2.23 * * *$ & 5.04 & $20.17 * * *$ & 2.91 & $22.94 * * *$ & $I(1)$ \\
\hline spread & -0.75 & $-3.84 * * *$ & 11.25 & $29.90 * * *$ & 11.82 & $18.66 * * *$ & $I(1)$ \\
\hline bank & $-1.35^{*}$ & $-3.45 * * *$ & 12.66 & $21.90 * * *$ & 7.63 & $22.17 * * *$ & $I(1)$ \\
\hline penetra & 1.22 & $-2.99 * * *$ & 2.43 & $23.22 * * *$ & 3.34 & $38.60 * * *$ & $I(1)$ \\
\hline findev & 0.88 & $-6.10 * *$ & 3.95 & $46.90^{* * * *}$ & 6.91 & $49.79 * * *$ & $I(1)$ \\
\hline
\end{tabular}

Note: $*$, **, and *** indicate that the test statistic is significant at the $10 \%, 5 \%$, or $1 \%$ level.

Source: Authors' calculations.

Table 5

Panel Unit Root Tests (new 11 EU member states)

\begin{tabular}{|l|c|c|c|c|c|c|c|}
\hline \multirow{2}{*}{ Variables } & \multicolumn{2}{|c|}{$\begin{array}{c}\text { Im, Pesaran and Shin } \\
\text { W-stat }\end{array}$} & \multicolumn{2}{|c|}{ ADF-Fisher Chi square } & \multicolumn{2}{c|}{ PP-Fisher Chi square } & Implication \\
\cline { 2 - 8 } & $\begin{array}{c}\text { At } \\
\text { a level of }\end{array}$ & $\begin{array}{c}\text { First } \\
\text { differentiation }\end{array}$ & $\begin{array}{c}\text { At } \\
\text { a level of }\end{array}$ & $\begin{array}{c}\text { First } \\
\text { differentiation }\end{array}$ & $\begin{array}{c}\text { At } \\
\text { a level of }\end{array}$ & $\begin{array}{c}\text { First } \\
\text { differentiation }\end{array}$ & \\
\hline ofi & 0.02 & $-4.20 * * *$ & 20.91 & $57.64 * * *$ & 20.07 & $97.68 * * *$ & $I(1)$ \\
gdpg & 0.57 & $-4.10^{* * *}$ & $54.49 * * *$ & & 20.68 & $67.57 * * *$ & $I(1)$ \\
infl & 1.50 & $-2.87 * * *$ & $46.06 * * *$ & & 27.85 & $47.85 * * *$ & $I(1)$ \\
spread & 1.73 & $-5.69 * * *$ & $75.27 * * *$ & & 24.86 & $50.57 * * *$ & $I(1)$ \\
bank & 3.63 & $-5.11^{* * *}$ & 6.94 & $73.34 * * *$ & 10.89 & $111.8 * * *$ & $I(1)$ \\
penetra & 1.24 & $-4.29 * * *$ & 15.20 & $58.49 * * *$ & 22.26 & $125.4 * * *$ & $I(1)$ \\
findev & 0.12 & $-6.56 * * *$ & 19.19 & $86.04 * * *$ & 27.45 & $132.6 * * *$ & $I(1)$ \\
\hline
\end{tabular}

Note: $*$, **, and *** indicate that the test statistic is significant at the $10 \%, 5 \%$, or $1 \%$ level.

Source: Authors' calculations. 
Table 6

Results of Pedroni's and Kao's Panel Cointegration Tests

\begin{tabular}{|l|c|c|c|c|}
\hline \multirow{2}{*}{ Model } & $\begin{array}{c}\text { The Balkan } \\
\text { Group } \\
\text { (BAL-4) }\end{array}$ & $\begin{array}{c}\text { The Baltic } \\
\text { Group } \\
\text { (B-3) }\end{array}$ & $\begin{array}{c}\text { The Višegrad } \\
\text { Group } \\
\text { (VIS-3) }\end{array}$ & $\begin{array}{c}\text { 11 EU member } \\
\text { states }\end{array}$ \\
\cline { 2 - 5 } & Stat & Stat & Stat & Stat \\
\hline Panel v-Statistic & -1.388 & -0.959 & -1.288 & -1.96 \\
Panel rho-Statistic & 1.144 & 1.329 & 1.203 & -1.37 \\
Panel PP-Statistic & $-3.424^{* * *}$ & $-3.618^{* * * *}$ & $-0.800^{* * *}$ & $-1.500^{* * *}$ \\
Panel ADF-Statistic & $-2.830^{* * *}$ & $-2.261^{* * *}$ & -0.799 & $-6.44^{* * * *}$ \\
Group rho-Statistic & 2.232 & 1.976 & 2.078 & 4.12 \\
Group PP-Statistic & $-1.841^{* * *}$ & $-4.780^{* * *}$ & $-3.084^{* * *}$ & $-2.534^{* * * *}$ \\
Group ADF-Statistic & $-1.513^{* * * *}$ & $-2.263^{* * *}$ & -1.977 & $-4.70^{* * *}$ \\
\hline Kao Residual Cointegration Test & 0.000 & 0.041 & 0.071 & 0.077 \\
$(p$-value) & & & & \\
\hline
\end{tabular}

Note: *, **, and *** indicate that the test statistic is significant at the $10 \%, 5 \%$, or $1 \%$ level.

Source: Authors' calculations.

As presented in Table 6, the majority of Pedroni's $(1999 ; 2001)$ tests indicates that there is a cointegration relationship for all four models. The Kao (1999) test, as illustrated in Table 6, also indicates a cointegration relationship in all models.

Noting that all determinants in all models are co-integrated, in the next steps, we tested long-run linkage among the selected determinants and shadow banking using FMOLS and DOLS tests.

T a b l e 7

\section{Estimation Results}

\begin{tabular}{|c|c|c|c|c|c|c|c|c|}
\hline \multirow{2}{*}{$\begin{array}{l}\text { Sub-groups } \\
\text { Variables }\end{array}$} & \multicolumn{2}{|c|}{$\begin{array}{c}\text { The Balkan group } \\
\text { (BAL-4) }\end{array}$} & \multicolumn{2}{|c|}{$\begin{array}{l}\text { The Baltic group } \\
\text { (B-3) }\end{array}$} & \multicolumn{2}{|c|}{$\begin{array}{c}\text { The Višegrad group } \\
\text { (VIS-4) }\end{array}$} & \multicolumn{2}{|c|}{$\begin{array}{c}\text { Total } \\
(11 \text { NMS })\end{array}$} \\
\hline & FMOLS & $D O L S$ & FMOLS & DOLS & $F M O L S$ & $D O L S$ & FMOLS & $D O L S$ \\
\hline$g d p g$ & $\begin{array}{l}0.18 \\
(0.22)\end{array}$ & $\begin{array}{l}0.13 * * \\
(0.07)\end{array}$ & $\begin{array}{c}0.26^{*} \\
(0.08)\end{array}$ & $\begin{array}{l}0.64 * * * \\
(0.12)\end{array}$ & $\begin{array}{l}0.47 \\
(0.51)\end{array}$ & $\begin{array}{l}0.72 * * \\
(0.97)\end{array}$ & $\begin{array}{l}0.26 * * \\
(0.17)\end{array}$ & $\begin{array}{l}0.11 * * \\
(0.35)\end{array}$ \\
\hline infl & $\begin{array}{c}-0.22 * * \\
(0.14)\end{array}$ & $\begin{array}{c}-0.04 \\
(0.08)\end{array}$ & $\begin{array}{c}-0.45^{*} \\
(0.17)\end{array}$ & $\begin{array}{c}-0.22 * * \\
(0.19)\end{array}$ & $\begin{array}{c}-0.60 \\
(0.62)\end{array}$ & $\begin{array}{c}-0.55 \\
(1.16)\end{array}$ & $\begin{array}{c}-0.88 \\
(0.21)\end{array}$ & $\begin{array}{l}-0.76 \\
(0.43)\end{array}$ \\
\hline spread & $\begin{array}{c}0.89 \\
(0.27) \\
\end{array}$ & $\begin{array}{c}0.60 \\
(0.17) \\
\end{array}$ & $\begin{array}{l}0.87 * * * \\
(0.38)\end{array}$ & $\begin{array}{l}1.54 * * \\
(0.47)\end{array}$ & $\begin{array}{l}2.42^{* * * *} \\
(2.51)\end{array}$ & $\begin{array}{l}4.97 * * \\
(4.55)\end{array}$ & $\begin{array}{c}0.48 \\
(0.84) \\
\end{array}$ & $\begin{array}{l}0.10 \\
(1.66)\end{array}$ \\
\hline bank & $\begin{array}{l}0.21 * \\
(0.05)\end{array}$ & $\begin{array}{l}0.07 * * \\
(0.02)\end{array}$ & $\begin{array}{l}0.02 * * \\
(0.04)\end{array}$ & $\begin{array}{l}0.10^{* *} \\
(0.04)\end{array}$ & $\begin{array}{l}0.74 * * * \\
(0.20)\end{array}$ & $\begin{array}{l}0.82^{* *} * \\
(0.30)\end{array}$ & $\begin{array}{l}0.23^{* *} \\
(0.06)\end{array}$ & $\begin{array}{l}0.24 * * * \\
(0.11)\end{array}$ \\
\hline penetra & $\begin{array}{l}1.89 \\
(0.78) \\
\end{array}$ & $\begin{array}{l}1.19 \\
(0.68)\end{array}$ & $\begin{array}{l}1.70 \\
(0.78)\end{array}$ & $\begin{array}{l}1.35 * * \\
(1.55)\end{array}$ & $\begin{array}{l}2.38 * * * \\
(0.19)\end{array}$ & $\begin{array}{l}2.10^{*} \\
(0.52)\end{array}$ & $\begin{array}{l}-0.51 * * \\
(2.09)\end{array}$ & $\begin{array}{l}0.64 * * * \\
(3.50)\end{array}$ \\
\hline findev & $\begin{array}{l}1.08 \\
(0.10)\end{array}$ & $\begin{array}{l}1.77 \\
(0.51)\end{array}$ & $\begin{array}{l}2.12 \text { *** } \\
(1.8)\end{array}$ & $\begin{array}{c}2.09 * \\
(1.23)\end{array}$ & $\begin{array}{l}2.97 * * * \\
(1.96)\end{array}$ & $\begin{array}{l}3.30 * * \\
(3.18)\end{array}$ & $\begin{array}{l}1.73 \\
(1.57)\end{array}$ & $\begin{array}{l}1.96 \\
(0.93)\end{array}$ \\
\hline crisis & $\begin{array}{l}-1.54 \\
(2.10) \\
\end{array}$ & $\begin{array}{l}-2.48 \\
(1.98) \\
\end{array}$ & $\begin{array}{l}-2.99 * \\
(1.3)\end{array}$ & $\begin{array}{l}-3.73 * * \\
(2.03)\end{array}$ & $\begin{array}{c}2.02 \\
(4.83)\end{array}$ & $\begin{array}{l}1.82 * * \\
(8.71)\end{array}$ & $\begin{array}{l}3.65 * * * \\
(1.65)\end{array}$ & $\begin{array}{l}3.76 * * \\
(3.23)\end{array}$ \\
\hline
\end{tabular}

Note: $* * *$, and $* * *$ indicate that the test statistic is significant at the $10 \%, 5 \%$, or $1 \%$ level. Standard errors in parentheses.

Source: Authors' calculations. 
Based on the results of FMOLS and DOLS tests, we can provide evidence that financial variables play a key role in the development of shadow banking. From the results concerning the three sub-groups and entire sample, we conclude that the asset size of banks (banks) is a statistically significant determinant with a positive coefficient. In the case of the Višegrad group of countries, the coefficient has the highest magnitude. This is not surprising given that they have the most developed banking and financial sectors, i.e., they offer a multitude of other financial products where shadow banking can be embedded. These results support the hypothesis that the development of this particular segment of the financial system goes hand in hand with non-traditional (shadow) banking. Therefore, there is strong evidence that the hypothesis of complementarity between the two sectors holds, supporting the view that market-based finance can progress alongside traditional banking. This could also point to the existence of some common roots between both processes (such as the development of ITC technologies, European integration, and financial innovation), resulting in a generalised development of the financial system (Apostoaie and Bilan, 2019).

Furthermore, the estimation results with the FMOLS suggest that insurance companies' penetration has a statistically significant impact on shadow banking in the Višegrad Group and in all 11 new EU member states, while the results of DOLS estimation confirm the previous results of FMOLS estimation. Additionally, this determinant was significant for the Baltic countries. Therefore, a $1 \%$ increase of insurance penetration is expected to result in an increase of shadow banking between $0.64 \%$ in all 11 NMS and $2.38 \%$ in the Višegrad Group. This result is not surprising as insurance companies provide protection against financial loss and subscribe collateralised debt obligations to invest their cash. Moreover, the insurance companies invest in securities issued in the shadow credit intermediation process, such as asset-backed commercial papers, assetbacked securities, and collateralised debt obligations (Hodula, 2018).

The results regarding the financial development index are consistent with that of the other financial variables. They reveal that the determinant has a positive impact on shadow banking, although it is only significant in the Baltic and Višegrad group of countries. A $1 \%$ increase of the financial development index is likely to lead to the growth of shadow banking by $2.12 \%$ in the Baltic countries and $3.30 \%$ in the Višegrad Group. These results are unsurprisingly in line with the results of Hodula (2018) because these group of countries have more developed financial sectors, and the growth of OFIs is demonstrated by the use of securitised products in these markets. In other words, the growth of shadow banking is much more likely in a fully fledged market economy that expands with the level of financial development and financial literacy. 
From a macroeconomic perspective, the results for banks' interest margin (spread) suggest that the determinant has a positive sign, but it is statistically significant only in the case of the Baltic and Višegrad countries. Given the relatively lower interest margin, the traditional banks in the Baltic and Višegrad countries shift their operations towards shadow-banking products. These results are in line with the results of Kim (2016), where this determinant was statistically significant and had a positive sign with values between $1.5 \%$ and $4.5 \%$. In this study, the coefficient was $1.54 \%$ for the Baltic states and $4.97 \%$ for the Višegrad countries. The corollary is that if the interest margin rises by $1 \%$, shadow banking will grow by between $1.54 \%$ in the Baltic nations and $4.97 \%$ in the Višegrad Group.

Moreover, the results reveal that the real GDP growth has a positive impact on shadow banking in all four groups of countries (three sub-groups and the entire sample) with almost similar results. The positive signs are in accordance with the relevant academic literature. This may be because the main function of the shadow banking sector in the NMS is due to its particular structure (consisting mainly of leasing and factoring companies, credit unions, cooperative banks, microfinance companies, and pawn shops), that of providing alternative funding to the economy, as pointed out by Ghosh et al. (2012). As Du, Li and Wang (2017) also mention in their work, in NMS, many credit institutions generally focus more on households (i.e., mortgage loans) than on enterprises. Moreover, from the bank operations performed for enterprises, a significant number involves processing payments instead of credit provision. Therefore, as many companies are unobserved or underserved by the formal financial system (Haselmann, Wachtel and Sobott, 2016), they are searching for finances from outside their traditional suppliers.

The results for the inflation rate concur with our expectation and are of a negative sign, but this determinant was significant in the Balkan and Baltic countries when we applied the FMOLS method. This implies that an increase of the inflation rate will have a negative impact on the size of the shadow banking system; it would reduce the size of the shadow banking, to a certain extent, due to the high cost of financing. According to Bencivenga and Smith (1993), governments are reluctant to impose additional tax burden on the financial sector to narrow the budget deficit in inflationary periods. It has been tested that inflation blocks the performance of markets by discouraging the level of investment in the economy. Its statistically significant impact on shadow banking in the Balkan and the Baltic group of countries is not surprising. In some countries in these regions, for example, Romania and Latvia, the inflation rate was $45.5 \%$ and $15.4 \%$ over a certain period. This implies that the countries, or at least some of them, have faced large inflation rates, unlike, for example, the Višegrad countries, where the highest inflation rate was observed in Slovakia in 2000 that amounted to $10 \%$. 
Lastly, we found that the crisis-related dummy variable had a diverse impact on the selected groups of countries. The shadow banking in the Baltic states decreased as a result of the global financial crisis, while the crisis did not affect the shadow banking system in the Balkan countries. Among the other groups of countries (the Višegrad Group and the entire sample of 11 NMS), we identified that the NMS experienced a more significant increase of shadow banking. The results confirm institutional cash pools and the search for yield hypotheses, showing that in a low interest-rate environment like the one following the financial crisis in CEE, the search for higher yield makes investors turn to shadow banking products. Moreover, the hypothesis of complementarity between the development of shadow banking and of the rest of the financial system is confirmed as well, probably with stronger evidence given the nature of the bankbased economy in CEE countries. In these economies, shadow banks provide alternative funding where traditional banking is not able to do so. These results are entirely consistent with those of Hodula (2018) for almost the same group of countries where this determinant was statistically significant and had a positive sign with a value of 2.24. Such significant differences could be explained by the rapid growth of the financial sectors in the selected group of countries, accompanied by the asset growth of other financial institutions and a more intensive use of securitised products.

\section{Conclusion}

The shadow banking system has played one of the central roles in the global financial crisis of $2007-2008$, although it is still an ongoing discussion whether it was merely an amplifier or originator. This banking segment provided easy and 'inexpensive' access to credit intermediation during the economic boom of early 2000s, especially in the United Kingdom and the United States that have more developed and diversified shadow banking systems compared with the other advanced economies (e.g., Germany and France). A significant expansion of the shadow banking system was also experienced in Central and Eastern Europe, or more precisely, in the 11 new EU member states.

The central goal of this study was to empirically investigate the driving forces of shadow banking in 11 NMS using annual data for the period $1999-2019$. To our best knowledge, this is the first time that NMS are classified into three subsamples (or sub-groups) and then separately analysed with respect to the determinants of shadow banking. We split the NMS into three more homogenous groups: Balkan countries (BAL-4), Baltic countries (B-3), and Višegrad countries (VIS-4). Using the FMOLS and DOLS estimation techniques, we found that 
the shadow banking sector (in terms of the total assets of other financial intermediaries as a percent of the GDP) has been positively influenced by, among other things, the developments in the insurance and banking sectors, as well as by the general financial and economic growth in all groups of countries. We also discovered that the GFC 2007 - 2008 had a diverse impact on the selected groups of countries. The Baltic countries particularly experienced a significant decrease in shadow banking, while the global crisis did not affect the shadow banking system in the Balkan countries. Furthermore, in the other group of countries (the Višegrad Group and 11 NMS), the estimation results demonstrate that GFC had a significant positive effect on shadow banking.

Such significant differences could be explained by the rapid growth of financial sectors in the selected group of countries, in addition to the asset growth of other financial institutions and a more intensive use of securitised products.

The results of the study addressed a number of aspects that regulatory authorities should keep them in mind: they should work on possible regulatory options, which may concern either the key components of shadow banking, addressing relevant activities, and/or entities (direct regulation), or the interaction of the regulated banking sector with shadow banking (indirect regulation).

\section{References}

APOSTOAIE, C. - BILAN, I. (2019): Macro Determinants of Shadow Banking in Central and Eastern European Countries. Economic Research - Ekonomska Istraživanja, 33, No. 1. pp. 1146 - 1171. Available at: <doi.org/10.1080/1331677X.2019.1633943>.

ADRIAN, T. - SHIN, H. S. (2009): The Shadow Banking System: Implications for Financial Regulation. Banque de France Financial Stability Review, No. 13, pp. 1 - 10.

AFONSO, A. - JALLES, T. (2012): Do Fiscal Rules Matter for Growth? [Working Paper, No. 07/2012/DE/UECE.] Lisbon: ISEG Department of Economics. Available at: $<$ http://dx.doi.org/10.2139/ssrn.2009616>.

BARBU, T. C. - BOITAN, I. A. - CIOACA, S. I. (2016): Macroeconomic Determinants of Shadow Banking - Evidence from EU Countries. Review of Economic and Business Studies, 9, No. 2, pp. 111 - 129. DOI: 10.1515/rebs-2016-0037.

BANERJEE, M. (1999): Panel Data Unit Roots and Cointegration: An Overview. Oxford Bulletin of Economics and Statistics, 61, No. S1, pp. $607-29$.

BENCIVENGA, V. - SMITH, B. (1993): Some Consequences of Credit Rationing in an Endogenous Growth Model. Journal of Economic Dynamics and Control, 17, No. 1 - 2, pp. 97 - 122.

BUJTÁR, Zs. - KECSKÉS, A. (2015): Where Is Heading the Legal Regulation after the Quaestor Scandal? Gazdaság és Jog, 23, No. 11, pp. 3 - 8 .

BROOS, M. - CARLIER, K. - KAKES, J. - KLAAIJSEN, E. (2012): Shadow Banking: An Exploratory Study for the Netherlands. Amsterdam: De Nederlandsche Bank.

DU, J. - LI, C. - WANG, Y. (2017): A Comparative Study of Shadow Banking Activities of Nonfinancial Firms in Transition Economies. China Economic Review, 46, Supplement, pp. S35 - S49. DOI: 10.1016/j.chieco.2016.09.001. 
DUCA, J. V. (2016): How Capital Regulation and other Factors Drive the Role of Shadow Banking in Funding Short-term Business Credit. Journal of Banking \& Finance, 69, pp. 10 - 24. DOI: 10.1016/j.jbankfin.2015.06.016.

ESRB (2016): EU Shadow Banking Monitor. Vol. 1, July. Frankfurt am Main: European Systemic Risk Board.

FINANCIAL STABILITY BOARD (2011): Shadow Banking: Scoping the Issues. Basel: Bank for International Settlements.

FINANCIAL STABILITY BOARD (2019): Global Monitoring Report on Non-bank Financial Intermediation 2018. Basel: Bank for International Settlements.

GIRON, C. - MATAS-MIR, A. (2017): Interconnectedness of Shadow Banks in the Euro Area. In: BANK FOR INTERNATIONAL SETTLEMENTS (ed.): Data Needs and Statistics Compilation for Macroprudential Analysis. Vol. 46. Basel: Bank for International Settlements.

GHOSH, S. - GONZALEZ DEL MAZO, I. - ÖTKER-ROBE, I. (2012): Chasing the Shadows: How Significant Is Shadow Banking in Emerging Markets? Economic Premise, 88, No. 72445, p. 7.

EUROPEAN COMMISSION (2012): Green Paper on Shadow Banking. Brussel: EC.

HASELMANN, R. - WACHTEL, P. - SOBOTT, J. (2016): Credit Institutions, Ownership and Bank Lending in Transition Economies. In: BECK T. and CASU B. (eds): The Palgrave Handbook of European Banking. London: Palgrave Macmillan.

HODULA, M. - MELECKY, A. - MACHACEK, M. (2017): Off the Radar: Factors behind the Growth of Shadow Banking in Europe. SSRN Electronic Journal. Available at: <doi.org/10.1016/j.ecosys.2020.100808>.

HODULA, M. (2018): Off the Radar: Exploring the Rise of Shadow Banking in the EU. [The Working Paper Series.] Prague: The Czech National Bank (CNB).

IMF (2014): Shadow Banking around the Globe: How Large, and How Risky? In: Global Financial Stability Report. Risk Taking, Liquidity, and Shadow Banking. Curbing Excess while Promoting Growth, pp. $65-104$.

IM, K. S. - PESARAN, H. - SHIN, Y. (2003): Testing for Unit Roots in Heterogeneous Panels. Journal of Econometrics, 115, No. 1, pp. 53 - 74.

KAO, C. (1999): Spurious Regression and Residual-based Tests for Cointegration in Panel Data. Journal of Econometrics, 90, No. 1, pp. $1-4$

KAO, C. - CHIANG, M. (2000): On the Estimation and Inference of a Cointegrated Regression in Panel Data. Advances in Econometrics, 15, pp. 179 - 222.

KIM, S. (2016): What Drives Shadow Banking? A Dynamic Panel Evidence. [Paper Presented at the Eighth IFC Conference on 'Statistical Implications of the New Financial Landscape'.] Basel.

LEAN, H. - SMYTH, R. (2010): On the Dynamics of Aggregate Output, Electricity Consumption and Exports in Malaysia: Evidence from Multivariate Granger Causality Tests. Applied Energy, 87, No. 6, pp. 1963 - 1971. Available at: <doi.org/10.1016/j.apenergy.2009.11.017>.

MADDALA, G. S. - WU, S. (1999): A Comparative Study of Unit Root Tests With Panel Data and a New Simple Test. Oxford Bulletin of Economics and Statistics, 61, No. S1, pp. 631 - 652.

MADDALA, G. S. (2001): Introduction to Econometrics. 3rd Edition. New York: Wiley.

MALATESTA, F. - MASCIANTONIO, S. - ZAGHINI, A. (2016): The Shadow Banking System in the Euro Area: Definitions, Key Features and the Funding of Firms. Italian Economic Journal, 2, No. 2 pp. $217-237$.

MASIH, A. - MASIH, R. (1996): Energy Consumption, Real Income and Temporal Causality: Results from a Multi-country Study Based on Cointegration and Error-correction Modelling Techniques. Energy Economics, 18, No. 3, pp. 165 - 183.

MARTINEZ-MIERA. D. - REPULLO, R. (2015): Search for Yield. PIMCO Global Central Bank Focus, No. 2.

MÉRÖ K. - BETHLENDI, A. (2020): Changes in the Structure of Financial Intermediation Eastern-Central European Developments in the Light of Global and European Trends. Danube, 11, No. 4, pp. 283 - 299. DOI: 10.2478/danb-2020-0017. 
PEDRONI, P. (1999): Critical Values for Cointegration Tests in Heterogeneous Panels with Multiple Regressors. Oxford Bulletin of Economics and Statistics, 61, No. S1, pp. 653 - 670.

PEDRONI, P. (2001): Purchasing Power Parity Tests in Cointegrated Panels. Review of Economics and Statistics, 83 , pp. $727-731$.

PORTES, R. (2018): Interconnectedness: Mapping the Shadow Banking System. Banque de France European Stability Review, 22, pp. 2 - 10.

ROODMAN, D. (2009): How to Do xtabond2: An Introduction to Difference and System GMM in Stata. The Stata Journal, 9, No. 1, pp. $86-136$.

SVIRYDZENKA, K. (2016): Introducing a New Broad-based Index of Financial Development. [IMF Working Paper, No. WP/16/5.] Washington, DC: International Monetary Fund. 